\title{
PSEUDO-ABSCESS OF THE PSOAS BURSA IN FAILED DOUBLE-CUP ARTHROPLASTY OF THE HIP
}

\author{
DONALD W. HOWIE, CHRISTOPHER M. J. CAIN, BRIAN L. CORNISH
}

From Royal Adelaide Hospital, South Australia

\begin{abstract}
Seven psoas bursae filled with purulent fluid and inspissated debris were revealed at revision operations for failed resurfacing hip arthroplasties, an incidence of $5.8 \%$ in such revisions.

Histological and microbiological investigations demonstrated that the psoas bursa collections resulted from the tissue response to polyethylene wear debris. None was due to infection.
\end{abstract}

Psoas bursitis occurs in association with inflammatory hip disorders, usually caused by infection (Coventry, Polley and Weiner 1959; Steinbach et al 1985; Jaffray and Nade 1986; Binek and Levinsohn 1987). Bursae have also been found during arthrographic investigation of painful hip arthroplasties (Steinbach et al 1985; Berquist et al 1987).

The finding, during revision hip arthroplasty, of a collection of purulent fluid or necrotic inspissated debris anterior to the hip joint may cause considerable concern to the surgeon because of the possibility of an infective aetiology. The aim of this study was to investigate, by histological and microbiological examination, the aetiology of a series of distended bursae so encountered.

\section{MATERIAL AND METHODS}

Psoas bursa collections were found in seven patients, four male and three female, in a series of 121 revisions of Wagner double-cup hip arthroplasties. The patients' ages ranged from 41 to 74 years (median 60 ). The primary diagnosis was osteoarthritis in six and rheumatoid arthritis in one. The revision operations were performed over a five-year period by two surgeons (DWH and BLC).

All the primary procedures had been performed by one surgeon (BLC) through an anterior Smith-Petersen approach. Both the cobalt-chrome femoral component and the ultra-high molecular weight polyethylene acetabular component were fixed with acrylic cement using standard techniques.

D. W. Howie, PhD, FRACS, Professor and Head of Department C. M. J. Cain, MB BS, Trauma Research Fellow

B. L. Cornish, FRCS, FRACS, Honorary Senior Visiting Orthopaedic Surgeon

Department of Orthopaedic Surgery and Trauma, Royal Adelaide Hospital, North Terrace, Adelaide, South Australia 5000, Australia.

Correspondence should be sent to Professor D. W. Howie.

(C) 1991 British Editorial Society of Bone and Joint Surgery 0301-620X/91/1025\$2.00

J Bone Joint Surg [Br] 1991 ; 73-B :29-32.
Prior to revision arthroplasty, one patient underwent arthrography of the hip in addition to standard radiographs. At revision arthroplasty, which included capsulectomy, the appearance of the joint and any associated collections were recorded. The degree of loosening at the prosthesis-cement and bone-cement interfaces was estimated by widely exposing the interfaces and pushing and pulling on the implant.

Tissue biopsies taken from the seven hips included the psoas bursa and its contents: capsule, for frozen section and definitive histological examination; connective tissue from the acetabular bone-cement interface; connective tissue from the femoral bone-cement interface (if the prosthesis was loose) or the whole femoral head and intact femoral component (if it was not loose). The specimens were fixed in formalin, cleared in xylene

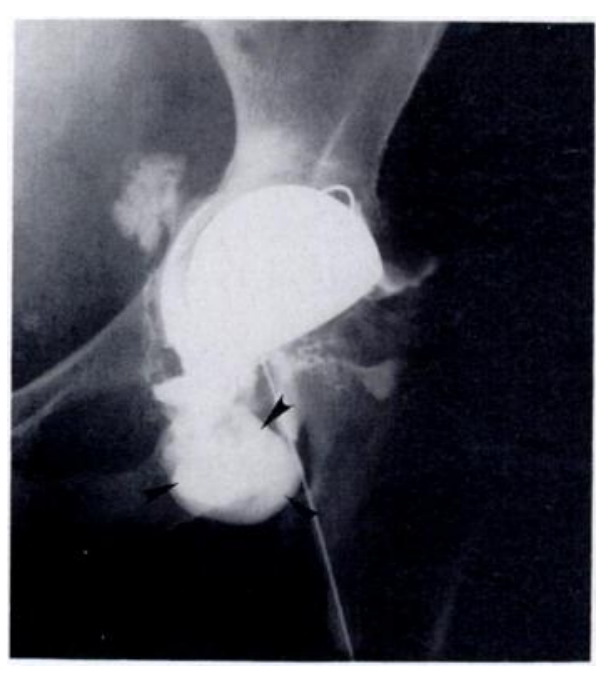

Fig. 1

Anteroposterior arthrogram showing a collection of contrast material (arrows) medial to the hip and femoral neck. In the lateral view the collection was seen to extend anteromedially and above the hip joint. 
and alcohol, and embedded in wax. Thin sections were prepared and examined under direct and polarised light.

Tissue specimens were also taken for microbiological examination as follows: three from the capsule, one from the acetabular bone-cement interface, one from the femoral bone-cement interface, and one from the bursal wall. Pre-operative aspiration of the hips was not routinely undertaken because of the high incidence of false-negative and false-positive results reported (Patel, Karchmer and Harris 1976; Buchholz, Elson and Lodenkämper 1979).

Table I. The time from primary arthroplasty to revision and the degree of loosening of the components

\begin{tabular}{|c|c|c|c|c|c|}
\hline \multirow[b]{3}{*}{ Patient } & \multirow{3}{*}{$\begin{array}{l}\text { Time (mth) from } \\
\text { primary } \\
\text { arthroplasty }\end{array}$} & \multicolumn{4}{|c|}{ Loosening grade* } \\
\hline & & \multicolumn{2}{|c|}{ Acetabulum } & \multicolumn{2}{|c|}{ Femur } \\
\hline & & $\mathbf{P}-\mathbf{C} \boldsymbol{t}$ & $\mathbf{B}-\mathbf{C}+$ & $\mathbf{P}-\mathbf{C}$ & B-C \\
\hline JB & 72 & 0 & 1 & 0 & 0 \\
\hline ME & 90 & 3 & 3 & 0 & 0 \\
\hline SL & 53 & 3 & 3 & 0 & 3 \\
\hline DH & 94 & 3 & 3 & 0 & 0 \\
\hline NH & 98 & 3 & 3 & 0 & 0 \\
\hline $\mathrm{JC}$ & 32 & 0 & 3 & 0 & $\mathbf{0}$ \\
\hline PL & 72 & 0 & 0 & 3 & 1 \\
\hline
\end{tabular}

* 0 , no movement at the interface; 1 , fluid movement at the interface; 2 , slight rocking; 3 , grossly loose

t $\mathrm{P}-\mathrm{C}$, prosthesis-cement interface; $\mathrm{B}-\mathrm{C}$, bone-cement interface

Biopsy tissue was taken with separate uncontaminated instruments prior to antibiotic administration and sent to the laboratory in transport media. All specimens were cultured anaerobically and aerobically for 14 days using standard laboratory techniques and methods of bacterial identification (Cowan 1974; Holdeman, Cato and Moore 1977).

\section{RESULTS}

The psoas bursa masses were not identified pre-operatively in the first six patients. One patient (NH) was found pre-operatively to have a firm, slightly tender, fixed mass in the groin, approximately $10 \mathrm{~cm}$ by $6 \mathrm{~cm}$. Arthrography in this patient revealed a large psoas bursa communicating with the hip (Fig. 1). The bursal masses in the other patients were diagnosed at the time of anterior capsulectomy when the wound became filled with purulent fluid in one case and with serous fluid containing large amounts of debris in the others. Exploration of the origin of this material led to the identification of a collection in the immediately adjacent psoas bursa which contained further inspissated fluid and debris. The bursae were excised.
Table II. The types of prosthesis wear particles in the bursal walls, scored from 0 to $3+$ (Mirra et al 1976)

\begin{tabular}{|c|c|c|c|c|}
\hline \multirow[b]{3}{*}{ Patient } & \multicolumn{4}{|c|}{ Wear particles } \\
\hline & \multirow[b]{2}{*}{ Metal } & \multicolumn{2}{|c|}{ Polyethylene } & \multirow[b]{2}{*}{ Acrylic } \\
\hline & & $<100 \mu \mathrm{m}$ & $>100 \mu \mathrm{m}$ & \\
\hline JB & 0 & $3+$ & 0 & 0 \\
\hline ME & 0 & $3+$ & 0 & 0 \\
\hline SL & 0 & $2+$ & $1+$ & $\mathbf{0}$ \\
\hline DH & 0 & $3+$ & 0 & $1+$ \\
\hline NH & 0 & $3+$ & $3+$ & $3+$ \\
\hline $\mathrm{JC}$ & 0 & $2+$ & $1+$ & $1+$ \\
\hline PL & 0 & $3+$ & $3+$ & $3+$ \\
\hline
\end{tabular}

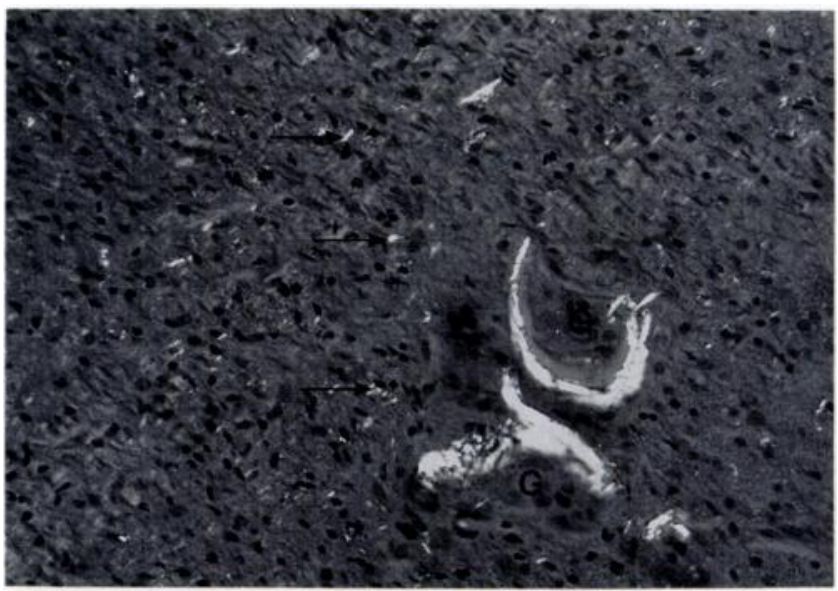

Fig. 2

Photomicrograph of a bursal wall viewed by polarised light. It shows large numbers of small polyethylene particles (arrows) contained in macrophages and large polyethylene particles surrounded by multinucleate giant cells $(G)$. (Haematoxylin and eosin, $\times 200$ ).

The degree of loosening of the femoral and acetabular components is shown in Table $\mathrm{I}$.

The histological features of the bursal walls are summarised in Tables II and III. They showed features typical of the tissue response to prosthesis wear particles (Vernon-Roberts and Freeman 1977). There were macrophages and multinucleate giant cells in association with large numbers of polyethylene particles and fewer acrylic particles. Many of the polyethylene particles were less than $5 \mu \mathrm{m}$ in maximum diameter (Fig. 2).

The surfaces of the bursal walls varied in appearance, either consisting of fibrin and necrotic tissue, or lined by polygonal and elongated cells. Neutrophil polymorphonuclear leucocytes were not seen, except for the occasional cell in the surface fibrin or around a blood vessel. In no areas were more than five neutrophil polymorphonuclear 
leucocytes seen per high-power field, and therefore the tissues were thought not to show histological evidence of infection (Mirra et al 1976).

All cultures were negative, except in one patient in whom an enterobacteria species was grown from two capsule biopsies after culture of one to two weeks. As only two of the five biopsies from this patient were positive, and those only in broth culture, the bacteria were assumed to be contaminants (Kamme and Lindberg 1981).

\section{DISCUSSION}

The incidence of bursal masses in our revised Wagner arthroplasties was $5.8 \%$ ( 7 of 121 cases), which seems high given the few reports in the literature of such collections around uninfected total hip arthroplasties (Steinbach et al 1985; Berquist et al 1987). We suggest that the inflammatory response is a result of excessive wear of the polyethylene component in this resurfacing design of arthroplasty (Howie, Wiadrowski and Cornish 1989). This is consistent with previous reports of psoas bursae communicating with the hip in the inflammatory arthropathies (Coventry et al 1959; Melamed, Bauer and Johnson 1967). The finding in this study of large numbers of polyethylene particles in the periprosthetic tissues around resurfacing hip arthroplasties agrees with other reports (Revell et al 1978; Bell et al 1985; Howie 1988), and the tissue response to these particles has been implicated in loosening of the prostheses (Revell et al 1978; Howie et al 1988).

Pseudo-abscesses may occur in association with severe wear of the polyethylene components of any design of hip arthroplasty. It is suggested that, armed with this knowledge and with a frozen section showing no histological evidence of acute inflammation, the surgeon may proceed to revision arthroplasty using techniques appropriate for aseptic loosening.

The authors acknowledge the assistance of $\mathbf{M}$. McGee and Jean McLean, Royal Adelaide Hospital; the staff of the Bone Laboratory, Institute of Medical and Veterinary Science; and the advice of Professor B. Vernon-Roberts, University of Adelaide.

This study was supported by grants from the Adelaide Bone and Joint Research Foundation and the Australian National Health and Medical Research Council.

No benefits in any form have been received or will be received from a commercial party related directly or indirectly to the subject of this article.

Table III. Histological appearance of the psoas bursa walls, with cell scores from 0 to $3+$ (Mirra et al 1976)

\begin{tabular}{|c|c|c|c|c|c|}
\hline \multirow[b]{3}{*}{ Patient } & \multirow[b]{3}{*}{ Histology } & \multicolumn{4}{|c|}{ Cell score } \\
\hline & & \multicolumn{2}{|c|}{ Inflammatory } & \multirow[b]{2}{*}{ Macrophages } & \multirow[b]{2}{*}{ MNGC } \\
\hline & & Acute & Chronic & & \\
\hline JB & $\begin{array}{l}\text { Sheets of macrophages } \\
\text { and MNGC*, surface } \\
\text { of polygonal and } \\
\text { elongated cells }\end{array}$ & 0 & $1+$ & $3+$ & $2+$ \\
\hline ME & $\begin{array}{l}\text { Sheets of macrophages } \\
\text { and MNGC, areas of } \\
\text { degeneration, surface } \\
\text { of fibrin and cell debris }\end{array}$ & $1+$ & $1+$ & $3+$ & $3+$ \\
\hline SL & $\begin{array}{l}\text { Collections of MNGC } \\
\text { and macrophages, } \\
\text { predominantly } \\
\text { connective tissue } \\
\text { surface lined by } \\
\text { elongated cells }\end{array}$ & $1+$ & $1+$ & $2+$ & $1+$ \\
\hline DH & $\begin{array}{l}\text { Collections of } \\
\text { macrophages in fibrous } \\
\text { tissue stroma, surface } \\
\text { lined by elongated cells }\end{array}$ & 0 & 0 & $2+$ & 0 \\
\hline NH & $\begin{array}{l}\text { Collections of MNGC } \\
\text { and macrophages, and } \\
\text { areas of degeneration, } \\
\text { surface of fibrin and } \\
\text { cell debris }\end{array}$ & $\mathbf{0}$ & $1+$ & $2+$ & $2+$ \\
\hline JC & $\begin{array}{l}\text { Collections of MNGC } \\
\text { and macrophages, } \\
\text { surface of fibrin and } \\
\text { cell debris }\end{array}$ & 0 & $1+$ & $2+$ & $1+$ \\
\hline PL & $\begin{array}{l}\text { Sheets of macrophages } \\
\text { and MNGC, surface of } \\
\text { fibrin and cell debris }\end{array}$ & $\mathbf{0}$ & $1+$ & $3+$ & $2+$ \\
\hline
\end{tabular}

- MNGC, multinucleate giant cells 


\section{REFERENCES}

Bell RS, Schatzker J, Fornasier VL, Goodman SB. A study of implant failure in the Wagner resurfacing arthroplasty. J Bone Joint Surg [Am] 1985; 67-A :1165-75.

Berquist TH, Bender CE, Maus TP, Ward EM, Rand JA. Pseudobursae. $A J R$ 1987; 148:103-6.

Binek R, Levinsohn EM. Enlarged iliopsoas bursa : an unusual cause of thigh mass and hip pain. Clin Orthop 1987; 224:158-63.

Buchholz HW, Elson R, Lodenkämper $\mathbf{H}$. The infected joint implant. In: McKibbin B, ed. Recent advances in orthopaedics No. 3. New York, etc: Churchill Livingstone Inc, 1979:139-61

Coventry MB, Polley HF, Weiner AD. Rheumatoid synovial cyst of the hip. J Bone Joint Surg [Am] 1959; 41-A :721-30.

Cowan ST. Cowan and Steel's manual for the identification of medical bacteria. Cambridge, etc: Cambridge University Press, 1974.

Holdeman LV, Cato EP, Moore WEC. Anaerobic laboratory manual. 4th ed. Blacksburg: Virginia Polytechnic Institute, 1977.

Howie DW. The osseous response to injury and implant fixation. In: Fitzgerald RH Jr, ed. Non-cemented total hip arthroplasty. New York: Raven Press, 1988:1-6.

Howie DW, Vemon-Roberts B, Oakeshott R, Manthey B. A rat model of resorption of bone at the cement-bone interface in the presence of polyethylene wear particles. J Bone Joint Surg [Am] 1988; 70 A:257-63.

Howie DW, Wiadrowski T, Comish BL. Wear of resurfacing arthroplasty acetabular components. Orth Research Soc. Las Vegas. 1989:407.
Jafiray DC, Nade S. Painless groin swelling associated with osteoarthritis of the hip. J R Coll Surg Edinb 1986; $31: 185-6$.

Kamme C, Lindberg L. Aerobic and anaerobic bacteria in deep infections after total hip arthroplasty: differential diagnosis between infectious and non-infectious loosening. Clin Orthop 1981; 154:201-7.

Melamed A, Bauer CA, Johnson JH. Iliopsoas bursal extension of arthritic disease of the hip. Radiology 1967; 89:54-8.

Mirra JM, Amstutz HC, Matos M, Gold R. The pathology of the joint tissues and its clinical relevance in prosthesis failure. Clin Orthop $1976 ; 117: 221-40$.

Patel D, Karchmer A, Harris WH. Role of preoperative aspiration of the hip prior to total hip replacement. The Hip: Procs of the 4th meeting of the Hip Society. St Louis, etc: CV Mosby Co, 1976: 219-23.

Revell PA, Weightman B, Freeman MA, Roberts BV. The production and biology of polyethylene wear debris. Arch Orthop Trauma Surg $1978 ; 91: 167-81$.

Steinbach LS, Schneider R, Goldman AB, Kazam E, Ranawat CS, Ghelman B. Bursae and abscess cavities communicating with the hip: diagnosis using arthrography and CT. Radiology 1985; 156:303-7.

Vernon-Roberts B, Freeman MAR. The tissue response to total joint replacement prostheses. In: Swanson SAV, Freeman MAR, eds. The scientific basis of joint replacement. London: Pitman Medical, 1977:86-129. 